\title{
GLL
}

믕 Geomatics, Landmanagement and Landscape No. $4 \cdot 2019,123-136$

\section{SIZE STRUCTURE OF INDIVIDUAL FARMS IN POLAND BETWEEN 1918-2018}

\author{
Aneta Dacko, Mariusz Dacko
}

\section{Summary}

This work contains a comparative analysis of the size structure of farms in Poland in three main time frames of the one hundred years since Poland regained statehood, i.e. the interwar period (1918-1939), the period of the People's Republic of Poland (1945-1989), and the period of the Third Polish Republic (1989-2018). Data sources included statistical yearbooks and literature on the subject. The periods considered in the work were periods of radical changes in the concept of shaping the agricultural sector. In the first period, dominated by the urgent need to rebuild the state and its economy, the development of full-fledged private farms was favoured. In the second period, in the face of changing political and economic conditions, these farms were often forcibly closed down, favouring socialist land ownership. In the third examined period, along with the transformation of the economy, the sector of state-owned agricultural holdings was liquidated. After difficult years of adjusting to the realities of free market economy, agriculture also experienced another change related to Poland's accession to the EU and functioning under the CAP. However, the research results prove that despite the political and socio-economic changes, and even despite radical political decisions, the farm size structure was characterized by a specific inertia. In the light of statistical data describing the centenary of Independent Poland, one can speak of the sustainability of the size structure of individual farms, demonstrating its high resistance to external factors and stimuli.

\section{Keywords}

agriculture $\bullet$ farm size structure $\bullet$ land fragmentation

\section{Introduction}

The history of the Polish countryside is filled with a series of periods during which social, economic, political and technological breakthroughs took place that were important for agriculture. In relation to the time frame outlined in the title of the study, three of these periods were analysed: the interwar period (1918-1939), the period of the People's Republic of Poland (1945-1989) and the period of the Third Polish Republic (1989-2018).

In each of the studied periods, the conditions relating to the functioning of agriculture were described and characterised. The shaping of the farm size structure was perceived as a result of changes in political and socio-economic impacts and interac- 
tions over time and space. This was a difficult task because the borders of the Polish state have changed over the last century. The administrative divisions of the state regions have also changed significantly several times. Some of the former Polish regions located outside of Poland's territory today. Therefore, it was only in the case of some area that the considerations on the continuity and changes in agriculture and its structures were justified actually. In addition, different understanding of the concept of farm (agricultural holding) was used in different periods of the considered timeline. And finally, which is also important: data on the size structure of Polish farming was collected and presented in various ways in different periods. All these factors combined to determine the impossibility of conducting comparative analyses in relation to identical areas, and in relation to the same juxtapositions of structures. However, what is interesting, despite these changes, the farm size structure of Polish individual agriculture revealed a remarkable continuity, inertia, and resistance to stimuli, which, it would seem, could have changed it dramatically, but did not.

In 1918 Poland became a free country, however, as shown by historical research, the stigma of partitions in many aspects still remains visible in Polish reality. The agrarian structure also is one of those aspects. Kłopot [2011] goes so far as to expresses the view that it is a typical "long term" (longue durée) structure. This author fittingly notes that during the partitions, during the inter-war period, than the "real socialism", and finally, after 1989, various factors determined the functioning of the countryside and agriculture, and yet we are dealing with the phenomenon of the relative stability of the agrarian structure. The main features of the spatial arrangement of countryside, shaped during the partitions, have survived to this day [Szymański 1969, Bański 2007, Musial 2010]: an agricultural landscape with visible large fragmentation in the shape of small plots, forming small farms in the south of the country, slightly larger farms in the northern part of Poland, and farms with large areas in the west of the country.

The goal of the study is a comparative analysis of the size structure of farms in Poland, in three basic time frames: the interwar period, the post-war period, and the period from economic transformation to the year 2018. Using the available statistical data, the authors attempt to verify the thesis about the sustainability and stability of the agrarian structure despite political, social, and economic conditions, which should theoretically change the outlook thereof. The study is of cognitive character combined with a theoretical review.

\section{Material and methods}

Statistical yearbooks were the basic source of data used in the present work. They were considered based on the division applied in the first available census from the period of independent Poland, which distinguished four districts of the country: Central, Western, Southern and Eastern (Table 1). These districts encompassed the voivodeships (regions) existing at that time.

Considering that after the Second World War the state borders and the country's administrative division changed, it was decided that selected representative voivode- 
ships (regions or provinces) would be adopted for further research. For the Central District it was Warsaw province, for the West it was the Poznan province, and for the South, the Kraków. province The problem arose in connection the Eastern District, because all the voivodeships (regions) it covered found themselves outside the Polish borders. Therefore, it was decided that post-war Białystok province should be chosen to represent the eastern part of the country. Another change in the administrative division from 1999 led to the situation, where in the last analysed period, the agrarian structure was considered regionally, in the layout resulting from the subdivision into new voivodeships (regions): Mazowieckie, Wielkopolskie, Małopolskie and Podlaskie (Table 1).

Table 1. The concept for studying farm size structure of agriculture according to regions

\begin{tabular}{|c|c|c|c|}
\hline & The interwar period & $\begin{array}{l}\text { The period } \\
\text { of People's Republic } \\
\text { of Poland }\end{array}$ & $\begin{array}{l}\text { The period } \\
\text { of the Third } \\
\text { Polish Republic }\end{array}$ \\
\hline Districts & Voivodships/regions & Voivodships/regions & Voivodships/regions \\
\hline Central & $\begin{array}{l}\text { białostockie, kieleckie, lubelskie, } \\
\text { łódzkie, warszawskie }\end{array}$ & warszawskie & mazowieckie \\
\hline West & $\begin{array}{l}\text { poznańskie, pomorskie, } \\
\text { śląskie (Górny Śląsk and Księstwo } \\
\text { Cieszyńskie) }\end{array}$ & poznańskie & wielkopolskie \\
\hline South & $\begin{array}{l}\text { krakowskie, lwowskie, } \\
\text { stanisławowskie, tarnopolskie }\end{array}$ & krakowskie & małopolskie \\
\hline East & $\begin{array}{l}\text { nowogródzkie, poleskie, } \\
\text { wołyńskie, wileńskie }\end{array}$ & białostockie & podlaskie \\
\hline
\end{tabular}

Source: Authors' own study

From the methodological point of view, it would be desirable to choose research areas designated within strictly defined spatial boundaries, and most importantly, within unchanging boundaries throughout the research period. Due to the specific conditions of the research, this is impossible. First of all, there is a lack of detailed data from the first analysed period. In addition, changes to the state borders, and later changes in the administrative boundaries of the country's provinces prevent the selection of spatially constant areas. It should also be noted that the authors' intention was not so much to thoroughly investigate the quantitative changes in the number of groups within the size structure of farms over the years, but rather to draw attention to the sustainability of these structures despite political, social and economic events that should theoretically result in distinct changes in the area size of agricultural holdings. 


\section{Political, social, and economic situation in particular periods covered by the study}

In theory, it is emphasized that the farm size structure of agriculture is influenced by variables in time and space, by the interactions of political, social and economic factors. It is impossible to clearly determine the impact of each of these factors, as well as their interrelationships, on changes in the size of farm holdings. However, the aforementioned factors cannot be ignored, because they seem to provide a particular stimulus for changes in the size structure of farms.

\subsection{The interwar period}

In 1918, after 123 years of partitions, Poland regained independence as a state. The time has come to rebuild the country, and in particular its economy, whose important branch was agriculture. The problem was very serious because, according to Bański [2007], in $192175 \%$ of the country's population lived in the countryside, and $63 \%$ of the working population lived off agriculture. Thus, the agricultural reform in Poland was one of the key economic and social issues of the interwar period. Already in 1919, the first decisions on the reform were made, and the following year, implementing regulations were developed. However, the reform did not survive in its original shape for too long. Its main provision, namely, the division of property for damages, in the amount of half of the market value, was deemed unconstitutional, which hindered the reform's implementation.

The issue of the reform of agriculture returned again in 1925. The new legal regulations provided for the purchase of land with full compensation. The goal was to create strong peasant-owned farms, known as "full-fledged farms", while maintaining landed estates of limited size but with modern management. Particular protection was extended over industrialized estates. By 1938, 2.65 million ha of land purchased was distributed, forming 153.6 thousand new farms with an average area of 9.3 ha. Existing small farms were also supplemented with land resources. Their area was additionally enlarged by an addition of 503,000 extra plots with an average area of 2.0 ha [Łoś 2006]. The reform was intended to create economic foundations for the further evolution of the Polish countryside, in a direction that resembled the western model. The reform's completion was prevented by the outbreak of World War II. The modernization of the Polish economy, aimed inter alia at shifting excess labour from agriculture to its other departments, was suddenly interrupted. Only after two decades of independence, Poland again experienced war and six years of devastating occupation.

\subsection{The period of the People's Republic of Poland}

The most important factor of changes in the agrarian structure of post-war Poland was the introduction of the Polish National Liberation Committee Decree on Agricultural Reform in 1944. According to communist practice, the basic intention of agriculture 
reform was its collectivization. Its intended effect was not so much to take control over the land, but to ensure effective control over the people associated with this land. This has often happened by introducing such conditions that led to the pathology of economic phenomena, irrational behaviour and demoralization of the village [Musiał 2008]. The base and background for all the changes was doctrinal and political, therefore, it was impossible to expect positive economic effects.

The main premises of the land reform undertaken at the beginning of the People's Republic of Poland included the division of all assets with an area exceeding 100 hectares, and all farms with an area exceeding 50 hectares (in western lands - exceeding 100 hectares). The owners of the confiscated land were not entitled to any compensation whatsoever. They were allowed to keep no more than 5 hectares of land, or to receive a monthly salary equal to the average wages of a government official. The peasants, on the other hand, had to pay an amount of one-year harvest from the obtained farm for the land received (free of the burden of debts). The repayment for the land was extended over a period of 10 to 20 years. In practice, the decree of the Polish Committee of National Liberation also often included those properties that did not meet the conditions specified therein. This was because as early as 1945 the Minister of Justice issued a circular in which he forbade land offices and courts to consider cases that would question the legitimacy of land seizure for the purposes of land reform and sanctioned all decisions in this field, regardless of whether they were taken in accordance with the provisions of the reform decree or not. Implementation of the decree was additionally supported by an extremely exploitive decree on the protection of the Polish state, issued on October 30, 1944 also by the Polish National Liberation Committee. Among other provisions of this was death penalty for hindering or obstructing land reform, and for calling for acts against that reform, and even for encouraging such acts in public. The previous landowners were therefore brutally removed from their estates, and following that, there were arrests and deportations of those who remained reluctant deep into the interior of Soviet Russia. These activities were accompanied by plunder and destruction of cultural heritage objects collected in landed gentry's manors. Repression was also used against the rural population who refused to participate in robberies of manors or division of land into plots. This state of affairs was sanctioned by the Constitution of 1952, which in its Article 3 stated that the People's Republic of Poland limits, displaces and liquidates social classes that had been living through the exploitation of workers and peasants.

In light of the Central Statistical Office data from 1950, peasant farms remained fragmented. The average farm size, which had been 5 ha in 1938, increased only to 5.4 ha in 1950. This was at the expense of destroying the landed gentry by brutal methods, demoralizing the countryside population, and squandering economic development in rural areas that began in the interwar period.

The long-term economic effect of implementing the decree was the creation of numerous, small and inefficient farms, which, combined with the ban on their sale and lease, slowed down economic development and intensified the overpopulation of the countryside, which is still felt today [Dobrzeniecki 2010]. 
Faced with difficult living conditions in the countryside and open disregard for individual ownership, farmers were increasingly moving to developing cities. There was a loss of land in private farming. But the peasant masses that remained in the countryside created such determined resistance against communist ideas that Poland came to be an exception throughout Central Europe in this respect. Indeed, it was only in Poland that individual agriculture survived until the fall of communism [Łoś 2006]. The vast majority of farms were small holdings, consisting of several hectares of land. Smallest farms were found in the south of the country, and the area increased the further north you went.

\subsection{The period of the Third Polish Republic}

In 1989 there was a gradual implementation of political changes, consisting in moving away from the centrally managed, "command and quota" economy towards a social market economy. However, the most important change that took place in the agricultural economy during the transformation period was the liquidation of the state sector and its environment [Bański 2007]. The privatization of unprofitable state farms, which often went bankrupt after the abolition of subsidies from the state, was to contribute to a radical change and improvement of the agrarian structure of Polish farming sector.

In 1989-1992 a process of stagnation in agriculture was observed, which was accompanied by a de-concentration of the size structure of farms. This was caused by a downturn in agriculture, and in particular by the increase in unemployment among the population (formerly two-occupational) causing family divisions of farms. The difficult financial situation of the agricultural population has contributed to the reduction of demand for state land (both for purchase and for lease). Under the new settlement policy, it was also impossible to develop state property in the Northern and Western Territories. It was estimated that the creation of a 30-50 hectare family farm required expenditures between 2.5 and 3 million zloty. It turned out that the rapid transformation of state-owned farms into family farms exceeded the financial capabilities of both the farmers themselves and the state budget. The introduction of a free market, which was to revive the economy and accelerate its development, did not bring the expected results in the field of improving the farm size structure of agriculture.

In the first years after the economic transformation, the economic situation of farmers was difficult; and it continued to deteriorate. The research of the Institute of Agricultural Economics and Food Economy showed that farms at the end of the 1990s were obtaining worse results compared to previous years [Bański 2007]. Similar opinions were expressed by experts from the Gdańsk Institute for Market Economics [2003]: "It should be noted that Polish agriculture, compared to other sectors of the economy, was included in the transformation process to a much lesser degree. Poland has also missed out on the process of decreasing the number of persons employed in agriculture, which is characteristic of countries with a well-established market economy, and is related to the increase in labour productivity in this particular sector." 
The low efficiency of Polish agriculture, and the size structure of farms that did not provide any prospects of increasing profitability were among the most serious development challenges of the Polish economy in the discussed period. It was becoming increasingly clear that Polish agriculture required systemic changes and thorough modernization [Dacko 2006]. According to Musiał [2008], the backwardness and the delays in the transformation and development of agricultural structures, agricultural culture, the organization of production and work, as well as in the achieved production effects dated back to cover the life span of one or two generations.

However, despite exploitative privatization and corruption, despite the downturn in agriculture, one can speak of a kind of continuity: the number of farms considered in individual regions and size groups remained similar to that observed in the 1950s and 1930s. The number of large farms has changed individually at most. After the next decades, statistics practically did not feature any farms over 50 hectares. Referring to these facts, Kłopot [2011] formulated the thesis on the farm size structure of agriculture as a "long term" (longue durée) structure - resistant to stimuli, which operated in such intensity that they should have changed it, at least theoretically.

Poland's accession to the European Union was an important moment in the development of Polish agriculture. However, the subject literature does not yet clearly distinguish this as a separate stage in the process. The inclusion of Poland in the Common Agricultural Policy (CAP) meant a substantial financial support for the countryside. A significant inflow of financial resources, both in the form of direct payments and as part of structural funds, was intended to contribute to the improvement of living conditions in the countryside. Aid from CAP was also intended to provide a positive impulse for structural changes in agriculture. Over time, however, justifiable reflections came to be voiced, stating that the planned changes in agriculture again did not go quite as expected.

The regulations included in the Common Agricultural Policy of the European Union translated into the size structure of farms in two ways. Cheaper social security contributions, together with various types of subsidies, contributed to a significant reduction in land turnover. At the same time, the value of land in Poland was constantly growing. Furthermore - even with the abandonment of agricultural production, and only maintaining the land in good agricultural culture - it brought owners a number of material benefits. The result was the polarization of farm size - the number of large sized farms increased, but the number of very small farms also increased [Otoliński 2007].

In the context of the failure of state interventionism in shaping the farm size structure of agriculture, it is useful to quote model research on the impact of subsidies on the size structure of the farms [Dacko and Płonka 2018]. The models present the results of implementing a number of instruments (i.e. support for agricultural product prices, subsidizing agricultural income, setting production quotas, or adopting set-aside policies). It was demonstrated that these instruments did not have the expected impact on the formation of a stable percentage of profitable farms with larger acreages. Indeed - after more than a decade of using costly CAP instruments, the agrarian structure of Polish agriculture (especially in southern regions) still deviates in a negative sense from such size parameters that would enable rational farming. 


\section{Comparative analysis of size structure of farm holdings in the light of statistical data}

The context of Polish agriculture's resistance to reforms, stimuli and external factors emerged from the synthesis of the cited theoretical studies. In these authors' opinion, it should manifest itself in the available statistical data by the relative continuity of the size structure of farms in the analysed period. Therefore, in the further part of the present work, the views on the permanence of the farm size structure, signalled in the literature, were verified in the light of official statistics. An attempt was made to answer the question whether the farm size structure of Polish agriculture in 2018, despite the lapse of the century, remained a similarly polarized structure of "long duration" as it was at the time when Poland regained independence. For this purpose, according to the methodology outlined in part two of the present paper (see Table 1), data from the agricultural censuses of interwar Poland $(1921,1931)$, as well as data from agricultural censuses and statistics of post-war Poland $(1950,1996,2018)$, have been summarized in tables and interpreted.

\subsection{The interwar period}

In the interwar period, the farm size structure of Polish agriculture was clearly differentiated between regions (Table 2), although as Kukuła aptly noted [2010], its detailed description in the form of numerical summaries was significantly hindered by the limited availability of agricultural statistics.

An important drawback of the first agricultural census in independent Poland (1921) was not only the fact that some areas of the country were omitted, but also that in individual districts other important characteristics were not studied - the number of farm holdings by size groups of agricultural land. The smallest farms (in the range of 0-2 ha) were considered together in one group, which hindered comparisons with the results of censuses carried out later (Table 2).

Table 2. Size structure of individual farms in 1921

\begin{tabular}{|l|r|r|r|r|r|c|}
\hline \multirow{2}{*}{ Districts } & \multicolumn{7}{|c|}{ Land area / percentage share } \\
\cline { 2 - 8 } & $\mathbf{0 - 2}$ ha & $\mathbf{2}-\mathbf{5}$ ha & $\mathbf{5 - 1 0}$ ha & $\mathbf{1 0 - 2 0}$ ha & $\mathbf{2 0 - 5 0}$ ha & $\mathbf{5 0}$ ha and above \\
\hline Central & 2 & 11 & 23 & 19 & 7 & 38 \\
\hline East & 1 & 10 & 17 & 13 & 7 & 52 \\
\hline West (excluding Silesia) & 2 & 3 & 7 & 16 & 15 & 57 \\
\hline South & 12 & 22 & 14 & 5 & 3 & 44 \\
\hline
\end{tabular}

Source: Kukuła [2010]

The census of 1921 was also burdened with certain measurement inaccuracies. As noted by Dziedzic [1928], in southern Poland, the owners eagerly volunteered size areas 
of wasteland and land not useful from an economic point of view. Areas of arable land and meadows were less eagerly given to interviewers, and pastures and forests were hardly considered. In the whole of Małopolska region, the accuracy of the 1921 census was low, and in mountainous areas, it was very low, because inaccuracy was compounded by distrust, and the difference between the official concepts and those held by the peasants.

The 1921 census covered four districts of Poland. The farm size structure emerged from it, within which one could notice a clear polarization of the land within individual farm size groups. Medium-sized farms (20-50 ha) had a relatively small percentage of arable land. They owned only: less than $3 \%$ of land resources in the Southern district, $7 \%$ in the Central and Eastern districts and $15 \%$ in the Western district. Against the background of other regions, significant fragmentation of agriculture was clearly visible in the then South district, where almost half of the arable land was owned by farm holdings with a total area not exceeding 10 ha (Table 2). In turn, the highest percentage of land owned by large-scale farms was recorded in the West district.

In addition to the data from 1921, another point of reference for the agrarian structure in the interwar period would be the results of the next census, which was carried out in 1931. As part of this census, the land area per individual farm size groups was not inventoried, but the number of farms in those groups was (Table 3). In this instance, the largest farms (with an area from 50 to $100 \mathrm{ha}$, and with an area larger than $100 \mathrm{ha})^{1}$ were considered together, in one group. The very concept of a "farm holding" ("gospodarstwo rolne") was replaced by the term "agricultural complex" ("zespół rolniczy").

Table 3. Size structure of individual farms in 1931

\begin{tabular}{|l|r|r|r|r|r|c|}
\hline \multirow{2}{*}{ Districts } & \multicolumn{6}{|c|}{ Number of farms / percentage share } \\
\cline { 2 - 7 } & $\mathbf{0 - 2}$ ha & $\mathbf{2}-\mathbf{5}$ ha & $\mathbf{5}-\mathbf{1 0}$ ha & $\mathbf{1 0 - 1 5}$ ha & $\mathbf{1 5}-\mathbf{5 0}$ ha & $\mathbf{5 0}$ ha and above \\
\hline Central & 16 & 39 & 32 & 8 & 4 & 1 \\
\hline East & 14 & 41 & 31 & 8 & 5 & 1 \\
\hline West & 12 & 21 & 26 & 18 & 20 & 3 \\
\hline South & 50 & 39 & 10 & 1 & 0 & 0 \\
\hline All Poland & 26 & 39 & 24 & 6 & 4 & 1 \\
\hline
\end{tabular}

Source: Mały rocznik statystyczny (Small statistical yearbook) 1939

This census, just like the previous one, showed many inaccuracies and shortcomings. Kukuła [2010] draws attention to the fact that over $8 \%$ of the surveyed farms were included in agricultural complexes of unknown size area. Despite this, and especially despite the reform of agriculture already underway at the time, it can be concluded that

1 Taking this fact into consideration, also in subsequent comparisons, farm size groups of 50-100 ha and above 100 ha were also considered jointly. 
in several respects the agrarian structure did not differ significantly from the structure observed ten years earlier: the largest percentage of large-scale farms still remained characteristic of Western Poland. Small-scale farms clearly dominated in Southern Poland.

\subsection{The period of the People's Republic of Poland}

Data from official statistics of the People's Republic of Poland period showed that smaller farms still dominated in the size structure of individual farms (Table 4). The most visible effect of the 1944 reform was the liquidation of farms in the size groups of 50-100 hectares and over 100 hectares. Data for Poland in general differ only slightly - despite the repressive agricultural reform implemented for the past 6 years, aimed at the destruction of the Polish landed gentry. The aforementioned policy was effective in one aspect: all practical purposes, the percentage of farms larger than 50 ha was reduced to zero for.

Table 4. Size structure of individual farms in 1950

\begin{tabular}{|l|c|c|c|c|c|c|}
\hline \multirow{2}{*}{ Voivodeships/regions } & \multicolumn{6}{|c|}{ Number of farms / percentage share } \\
\cline { 2 - 8 } & 0-2 ha & 2-5 ha & $\mathbf{5 - 1 0}$ ha & $\mathbf{1 0 - 1 4}$ ha & $\mathbf{1 4 - 5 0}$ ha & $\mathbf{5 0}$ ha and above \\
\hline warszawskie/Warsaw & 17 & 28 & 39 & 10 & 6 & 0 \\
\hline białostockie/Białystok & 9 & 22 & 42 & 16 & 11 & 0 \\
\hline poznańskie/Poznań & 29 & 18 & 29 & 14 & 10 & 0 \\
\hline krakowskie/Kraków & 41 & 41 & 15 & 2 & 1 & 0 \\
\hline All Poland & 26 & 31 & 31 & 8 & 4 & 0 \\
\hline
\end{tabular}

Source: Rocznik statystyczny (Statistical yearbook) $1955^{2}$

However, with a few exceptions, in the remaining size groups - both in general, and in particular, representative voivodeships (regions), the differences from the data of 1931 were relatively small - they rarely exceeded 10 percentage points, while the general tendencies in the shaping of area structures could be considered similar (especially by comparing the farm size structure of the Centre district with the structure of the warszawskie (Warsaw) voivodeship (region), and the structure of the South district with the structure of the krakowskie (Krakow) region. The largest changes were recorded for the East district represented in the new territorial division by the białostockie (Białystok) region - there was a clear decrease in the percentage of small farms (between 2 and 5 hectares), and for the West district represented by the poznańskie (Poznań) region - here, in turn, a significant increase was observed in the share of very small farms (with an area between 0 and 2 hetares).

2 Rocznik statystyczny (Statistical yearbook) 1955. GUS, Warszawa. 


\subsection{The period of the Third Polish Republic}

The dynamics of structures in the recent period was considered from the perspective of the 1996 agricultural census, coupled with the data of official statistics collected in the inter-census periods - for the year 2018. In 1996, after more than 50 years since the reform of the Polish National Liberation Committee, the size group of the largest farms still remains practically non-existent. On a national scale, the farm size structure remains very similar to the structure from the year 1950 (Table 5). In regional terms, only in 3 out of 30 groups subject to comparison (each with each), the differences were slightly more significant, ranging from 11 to 13 percentage points.

Table 5. Size structure of individual farms in 1996

\begin{tabular}{|l|c|c|c|c|c|c|}
\hline \multirow{2}{*}{ Voivodeships/regions } & \multicolumn{6}{|c|}{ Number of farms / percentage share } \\
\cline { 2 - 7 } & 1-2 ha & 2-5 ha & 5-10 ha & 10-15 ha & 15-50 ha & 50 ha and above \\
\hline mazowieckie/Mazowsze & 15 & 30 & 33 & 14 & 8 & 0 \\
\hline podlaskie/Podlasie & 9 & 16 & 29 & 24 & 22 & 0 \\
\hline wielkopolskie/Wielkopolska & 18 & 22 & 27 & 18 & 15 & 0 \\
\hline małopolskie/Małopolska & 39 & 47 & 13 & 1 & 0 & 0 \\
\hline All Poland & 23 & 32 & 26 & 11 & 8 & 0 \\
\hline
\end{tabular}

Source: GUS (Polish Statistical Authority) Local Data Bank ${ }^{3}$

Also in the 2018 figures (Table 6), there was a noticeable inertia of structures - especially in relation to the first four farm size groups.

Table 6. Size structure of individual farms in 2018

\begin{tabular}{|l|c|c|c|c|c|c|}
\hline \multirow{2}{*}{\multicolumn{1}{|c|}{ Voivodeships/regions }} & \multicolumn{6}{|c|}{ Number of farms / percentage share } \\
\cline { 2 - 8 } & $\mathbf{1 - 2}$ ha & $\mathbf{2 - 5}$ ha & $\mathbf{5 - 1 0}$ ha & $\mathbf{1 0 - 1 5}$ ha & $\mathbf{1 5 - 5 0 ~ h a ~}$ & $\mathbf{5 0}$ ha and above \\
\hline mazowieckie/Mazowsze & 13 & 30 & 30 & 13 & 13 & 1 \\
\hline podlaskie/Podlasie & 5 & 22 & 24 & 17 & 29 & 3 \\
\hline wielkopolskie/Wielkopolska & 15 & 25 & 23 & 15 & 19 & 3 \\
\hline małopolskie/Małopolska & 39 & 45 & 12 & 2 & 2 & 0 \\
\hline All Poland & 20 & 32 & 23 & 10 & 13 & 2 \\
\hline
\end{tabular}

Source: GUS (Polish Statistical Authority) Local Data Bank ${ }^{4}$

3 Individual agricultural holdings according to farm size group. 1996. Powszechny Spis Rolny (General Agricultural Census), Bank danych lokalnych GUS (Polish Statistical Authority Local Data Bank).

4 Land use and sown area in 2018. 2019. Główny Urząd Statystyczny (Polish Statistical Authority). Warszawa. 
It is worth noting the very slow increase in the share of the largest farms. Since the reform of 1944, which effectively eliminated them, it is only in the last presented breakdown of the farm size structure that one can observe their one-percent share of those in the scale of the country, and in the regions of Wielkopolska and Podlasie (wielkopolskie and podlaskie voivodeships).

\section{Conclusions}

The research results indicate slight and very unwilling changes in the size structure of farms in Poland over the 100 years of the country's independence. Looking at the political, social and economic conditions in this period, one can try to explain this phenomenon, and point to the reasons for the ineffectiveness of actions taken to increase the size of the farms.

During the People's Republic of Poland, the main problem of the Polish farmer was rather the defense of his own land, and only later, and with great determination - the development of agricultural production. Individual farmers, who were discriminated against, struggled to find their means of subsistence. It should not be surprising that the Polish farmer had conservative views and was strongly attached to his land and tradition. Among other things, this was the reason why he managed to preserve and retain his land during the period of socialism.

The agricultural reform introduced by the PKWN decree from 1944 dissolved all farm holdings with an area of over 50 hectares. Their restoration is extremely slow. In 2018 , only $3 \%$ of farms of this size were recorded in the wielkopolskie (Wielkopolska) and podlaskie (Podlasie) voivodeships (regions), and $1 \%$ in the mazowieckie (Mazowsze) voivodeship (region). In the małopolskie (Małopolska) region they do not even constitute $1 \%$. Also slight changes in other groups indicate a high resistance of the agricultural system and its farm size structure.

It was only in one instance that the attempts to interfere in the farm size structure could be considered effective: in the post-war period, when the repressive nature of the land reform led to the complete dissolution of the largest farm holdings. But even then, it can also be observed that these changes did not become permanent.

According to the present authors, agricultural structures, by their very nature, evolve over long periods of time, and are most effectively formed by the free market.

Considering the impact of the Common Agricultural Policy on Polish agriculture, it should be noted that it raises a lot of controversy not only because it seems to be quite effective in consolidating agrarian fragmentation in Poland, hindering the flow of land to better, more rational users. Each regulation has its unintended aspects: in the case of the CAP, we tend to shy away from the fact that aid to farmers in economically developed countries distorts the structure of trade and prices of agricultural products, and has a negative impact on food quality.

The challenges facing EU agricultural policy are changing. It is no longer in the interest of today's societies of European Community countries to merely obtain cheap mass-produced food. For more than a decade, the fact that the good condition of 
agriculturally used ecosystems is also a valuable product of agriculture is increasingly emphasized. Therefore, perhaps we should come to terms with the fact that fragmented Polish agriculture will remain so fragmented for a long time, and that it remain behind the agriculture of Western Europe in the pursuit of efficiency. Still, Poland with its agricultural land resources is and will continue to be a major food producer in Europe. And yet, according to the principle of sustainable development, it can easily become a leader in the preservation of durable and resilient agro-ecosystems for subsequent generations, especially in regions where there are no suitable conditions for the development of industrial-scale agriculture.

\title{
References
}

Bański J. 2007. Geografia rolnictwa Polski. PWE, Warszawa.

Dacko A. 2006. Tworzenie warunków do rozwoju terenów wiejskich poprzez scalanie gruntów - aspekt teoretyczny. Infrastruktura i Ekologia Terenów Wiejskich, 2(2), 29-39.

Dacko M., Płonka A. 2018. Economic Evaluation of Selected Agricultural Policy Instruments in the Light of the Model of Overproduction on the Cereal Market. Problems of Agricultural Economics, 354 (1), 129-148.

Dobrzeniecki K. 2010. Reprywatyzacja - problem nadal nierozwiązany. [W:] Infos - zagadnienia społeczno-gospodarcze. Wydawnictwo Sejmowe dla Biura Analiz Sejmowych.

Dziedzic F. 1928. Stan gospodarstw włościańskich w powiecie wadowickim. Państwowy Instytut Naukowy Gospodarstwa Wiejskiego, Warszawa.

Kłopot S. W. 2011. Struktura agrarna indywidualnego rolnictwa w latach 1945-2010. Annales Universitatis Mariae Curie-Skłodowska, Lublin. Polonia XXXVI, 2.

Kukuła K. (red.). 2010. Statystyczne studium struktury agrarnej w Polsce. Wydawnictwo Naukowe PWN, Warszawa.

Łoś M. 2006. Uwarunkowania gospodarcze dekretu o reformie rolnej z 6 września 1944 roku. Rolniczy Magazyn Elektroniczny, 14 (Centralna Biblioteka Rolnicza).

Mały rocznik statystyczny 1939. GUS. Warszawa

Musiał W. 2008. Ekonomiczne i społeczne problemy rozwoju obszarów wiejskich Karpat Polskich. Instytut Rozwoju Wsi i Rolnictwa Polskiej Akademii Nauk. Warszawa.

Musiał W. 2010. Determinaty rozwoju rolnictwa w regionach rozdrobnionych strukturalnie. Roczniki Naukowe Stowarzyszenia Ekonomistów Rolnictwa i Agrobiznesu, 12 (2).

Otoliński E. 2007. Przemiany w strukturze agrarnej w Polsce południowej w latach 1996-2005. Roczniki Naukowe Stowarzyszenia Ekonomistów Rolnictwa i Agrobiznesu, IX.

Rocznik statystyczny 1955. GUS. Warszawa.

Szymański M. 1969. Geodezja rolna w planowaniu przestrzennym. Państwowe Przedsiębiorstwo Wydawnictw Kartograficznych. Warszawa.

Ustawa z dnia 28 grudnia 1925 r. o wykonaniu reformy rolnej (Dz. U. R. P. z 1926 r. Nr 1, poz. 1).

\author{
Dr inż. Aneta Dacko \\ Uniwersytet Rolniczy w Krakowie \\ Katedra Geodezji Rolnej, Katastru i Fotogrametrii \\ ul. Balicka 253a, 30-198 Kraków \\ e-mail: a.dacko@ur.krakow.pl \\ ORCID: https://orcid.org/0000-0003-1470-5442
}


Dr inż. Mariusz Dacko

Uniwersytet Rolniczy w Krakowie

Instytut Ekonomiczno-Społeczny

Zakład Ekonomiki i Organizacji Rolnictwa

al. Mickiewicza 21, 31-120 Kraków

e-mail:m.dacko@ur.krakow.pl

ORCID: https://orcid.org/0000-0001-8424-4720 